\title{
Prediksi Farmakokinetik, Toksisitas, dan Aktivitas Enzim Protease HIV-1 Inhibitor dari Daun J. gendarussa
}

\author{
Agustinus Widodo* \\ Jurusan Farmasi Fakultas Matematika dan Ilmu Pengetahuan Alam Universitas Tadulako Palu
}

\begin{abstract}
Justicia gendarussa Burm.f. (Acanthaceae) telah diketahui memiliki aktivitas anti-HIV. Penelitian ini dilakukan untuk mengetahui interaksi flavonoid (gendarusin A, B, C, D, dan E) dari daun J. gendarussa terhadap reseptor protease HIV-1. Diharapkan penelitian ini akan memberikan informasi ilmiah tentang pengembangan daun $J$. gendarussa sebagai obat anti-HIV. Penelitian ini menggunakan metode uji in silico dengan FAF-Drugs4 untuk memprediksi ADMET (absorbsi, distribusi, metabolisme, dan ekskresi-toksisitas), dan Molegro Virtual Docker (MVD) untuk memprediksi aktivitas lima senyawa gendarusin terhadap reseptor protease HIV-1 (PDB ID: 4HLA). Prediksi aktivitas ini diamati dari ikatan hidrogen, ikatan sterik, dan rerank score yang ditampilkan pada program MVD. Senyawa gendarusin memiliki bioavailabilitas oral yang baik dan tidak beracun, dan dari uji docking molekul, diprediksi bahwa gendarusin daun J. gendarussa dapat menghambat aktivitas enzim protease HIV-1. Gendarusin dari J. gendarussa berpotensi sebagai anti-HIV.
\end{abstract}

Kata kunci: Justicia gendarussa Burm.f., protease HIV-1, in silico

\section{Prediction of Pharmacokinetics Toxicity and Protease HIV-1 Inhibitor Activity of $\boldsymbol{J}$. gendarussa Leaves}

Justicia gendarussa Burm.f. (Acanthaceae) has been known to have anti-HIV activity. This study was conducted to determine the interaction of flavonoids (gendarusin A, B, C, D, and E) on the J. gendarussa leaves against HIV-1 protease receptor. It is expected that this research will provide scientific information on the development of $J$. gendarussa leaves as an anti-HIV drug. This study used in silico testing methods with FAF-Drugs4 to predict the ADMET (absorption, distribution, metabolism, and excretion-toxicity), and Molegro Virtual Docker (MVD) to predict the activity of five gendarusin compounds to the receptor of HIV-1 protease (PDB ID: 4HLA). The activity prediction was reflected by hydrogen bond and steric bond visible in MVD program with amino acid residue of the receptor of HIV-1 protease. Gendarusin compounds had good oral bioavailability and were not toxic, and from molecular docking test, it was found that gendarusin of J. gendarussa leaves could inhibit the activity of HIV protease enzyme. Gendarusin of J. gendarussa has potential as an anti-HIV.

Keywords: Justicia gendarussa Burm.f., protease HIV-1, in silico

${ }^{*}$ Corresponding author: Jurusan Farmasi Fakultas Matematika dan IImu Pengetahuan Alam Universitas Tadulako, JI. Soekarno Hatta KM.9 Palu, e-mail: aureliasesy1@gmail.com 


\section{PENDAHULUAN}

HIV merupakan salah satu retrovirus yang menyerang sistem kekebalan tubuh manusia. HIV merusak sistem kekebalan tubuh dengan menghancurkan jenis sel darah putih yang disebut sel limfosit $\mathrm{T}$ yang pada permukaannya terdapat reseptor cluster of differentiation 4 (CD4). Ketika jumlah sel limfosit T-CD4 rendah maka seseorang lebih rentan terhadap infeksi tertentu (Pattman et al., 2005). Sistem kekebalan tubuh akan rusak secara perlahan seiring bertambahnya jumlah virus (viral load) dalam tubuh (Naif, 2013). Tahap akhir dari infeksi HIV adalah AIDS, yaitu ketika CD4 turun ke tingkat yang sangat rendah (biasanya $<200 \mathrm{sel} / \mathrm{mm}^{3}$ ), sehingga kemampuan untuk melawan infeksi tertentu secara serius terganggu (Pattman et al., 2005).

Salah satu pendekatan untuk pengembangan obat anti-HIV dapat dilakukan melalui program penelitian obat tradisional baik flora maupun fauna. Penelitian obat tradisional diarahkan untuk mencari bukti ilmiah tentang obat tradisional tersebut. Saat ini salah satu tanaman yang sedang dikembangkan sebagai antiHIV adalah Justicia gendarussa Burm.f. (Acanthaceae). Daun $J$. gendarussa mengandung amina aromatis tersubstitusi (Chakravarty et al., 1982), glikosida flavonoid yaitu gendarusin A dan B (Prajogo et al., 2009), dan alkaloid justidrusamida A, B, C dan D (Kiren et al., 2014). Komponen utama dalam ekstrak etanol 70\% adalah glikosida flavonoid apigenin yang disebut Gendarusin A (Prajogo et al., 2010). Senyawa flavonoid diketahui berperan sebagai sumber alami anti-HIV untuk terapi penderita (Veljkovic et al., 2007; Ko et al., 2009).

Hasil uji secara in vitro menggunakan ekstrak etanol 70\%, ekstrak etanol 70\% terfraksinasi, dan ekstrak air daun J. gendarussa menunjukkan aktivitas menghambat enzim reverse transcriptase HIV (Woradulayapinij et al., 2005; Prajogo et al., 2014). Penelitian terbaru uji ekstrak daun $J$. gendarussa pada kultur sel MOLT-4 yang terinfeksi HIV, hasilnya menunjukkan bahwa daun $J$. gendarussa dapat menghambat replikasi HIV melalui penurunan jumlah p24 dan penghambatan pembentukan syncytia (Widiyanti et al., 2015).

Pada penelitian ini dilakukan uji in silico untuk memprediksi ADMET (absorbsi, distribusi, metabolisme, ekskresi, dan toksisitas) senyawa gendarusin, dan uji in silico aktivitas antiHIVsenyawa gendarusin daun $J$. gendarussa melalui mekanisme penghambatan enzim protease HIV. Penelitian menggunakan metode in silico dipilih karena metode ini sering digunakan dalam penemuan dan pengembangan suatu obat, metode ini dapat memberikan penghematan baik dari segi biaya maupun waktu (Markus et al., 2003; Yanuar et al., 2011).

\section{METODE PENELITIAN Alat dan Bahan}

Software: ChemBio Draw Ultra 12.0 untuk menggambar struktur 2 Dimensi (2D) dan 3 Dimensi (3D) ligan, FAF-Drugs4 online untuk prediksi ADMET, dan Molegro Virtual Docker versi 5 untuk analisis docking Hardware: Komputer Windows 10 Pro, Intel(R) Core(TM) i33110M CPU @ 2.40GHz, RAM 2,00 GB, 64-bit Operating System, x-64based procesor. Struktur 2D dan 3D dari senyawa gendarusin daun Justicia gendarussa Burm.f. Reseptor Protease (PDB ID : 4HLA) yang diperoleh dari Protein Data Bank (http://www.rcsb.org/pdb/explore.do?structureId $=4 \mathrm{hla}$ ).

\section{Preparasi Struktur Protein}

Kristal protein dengan reseptor protease (PDB ID : 4HLA) ditambahkan atom $\mathrm{H}$ dan diperbaiki apabila ada kesalahan/kekurangan dari asam amino yang ada. Hal ini dilakukan secara otomatis oleh program Molegro Virtual Docker.

\section{Preparasi Ligan}

Menggambar struktur 2D dari struktur gendarusin $\mathrm{A}$, gendarusin $\mathrm{B}$, gendarusin $\mathrm{C}$, gendarusin $\mathrm{D}$ dan gendarusin $\mathrm{E}$ pada program ChemBioDraw Ultra 12.0. Masing-masing struktur di atas kemudian dijadikan struktur $3 \mathrm{D}$ dengan menggunakan program ChemBio3D Ultra 12.0, program ini dapat untuk melihat bentuk sterokimia senyawa dan mengatur bentuk yang paling stabil dari senyawa dengan cara meminimalkan energi, kemudian disimpan dalam bentuk file SYBYL.mol2, dan digunakan untuk proses docking.

\section{Prediksi ADMET Ligan}

Prediksi ADMET senyawa gendarusin menggunakan program FAF-Drugs4 online (http://mobyle.rpbs.univ-paris-diderot.fr/cgi-bin Lportal.py?form=FAF-Drugs4\#forms::FAF -Drug s4), program ini dapat memprediksi absorbsi, distribusi, metabolisme, ekskresi, dan toksisitas berdasarkan berat molekul, logP, tPSA, atau ikatan rotasi.

\section{Prediksi Aktivitas dengan Docking dan Analisis Asam Amino}

Docking menggunakan program Molegro Virtual Docker, dan asam amino yang terlibat pada proses interaksi obat reseptor dibandingkan antara masing-masing senyawa, demikian pula dengan nilai docking score. Senyawa dengan energi yang paling rendah menunjukkan interaksi obat-reseptor yang paling stabil, dan diprediksi mempunyai aktivitas biologis yang paling tinggi diantara senyawa-senyawa tersebut (Siswandono, 2011).

\section{HASIL DAN PEMBAHASAN Preparasi Ligan}

Hasil pembuatan struktur 2D dengan menggunakan program ChemBioDraw Ultra 12.0 ditunjukkan pada Gambar 1. Struktur 2D 
kemudian digunakan untuk membuat struktur 3D dengan menggunakan program ChemBio3D Ultra 12.0. Struktur $3 \mathrm{D}$ selanjutnya digunakan pada semua tahapan docking.

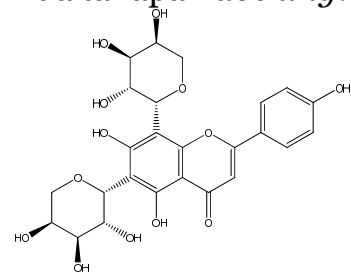

Gendarusin A

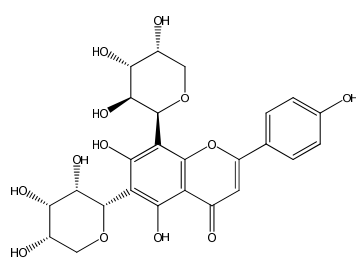

Gendarusin C

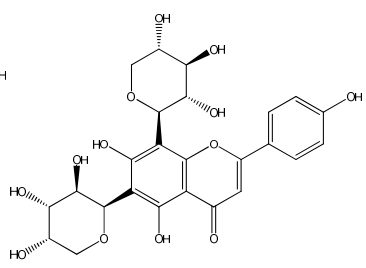

Gendarusin B

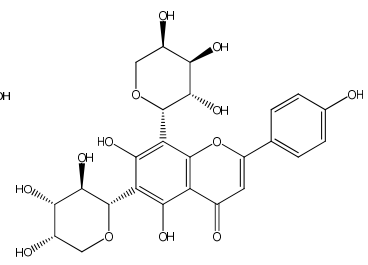

Gendarusin D

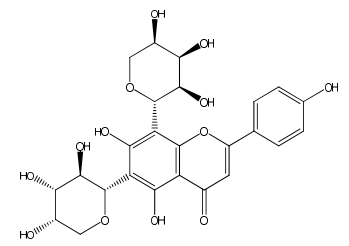

Gendarusin E

GAMBAR 1. Struktur 2 Dimensi Senyawa Gendarusin.

\section{Prediksi ADMET Ligan}

Skrining senyawa gendarusin (A, B, C, D, dan E) dan Darunavir ditentukan dengan menggunakan program FAF-Drugs4 dan hasilnya ditunjukkan pada Tabel 1. Lima senyawa gendarusin menunjukkan hasil yang sama, karena pebedaan posisi gugus gula yang terikat pada atom C6 dan C8 tidak mempengaruhi sifat kimia fisika senyawa secara in silico.

Hasil prediksi ADME menunjukkan lima senyawa gendarusin memiliki bioavailabilitas oral yang baik. Bioavailibilitas oral yang tinggi menjadi pertimbangan penting dalam mengembangkan molekul bioaktif. skrining bioavailibilitas oral suatu senyawa dilakukan berdasarkan dua aturan yaitu Veber's rule (Veber et al., 2002) dan Egan's rule (Egan et al., 2000). Berdasarkan Veber's rule suatu senyawa dapat dikatakan memiliki bioavailibilias oral yang baik jika: ikatan rotasi $\leq$ 10; tPSA (topological polar surface area) $\leq 140 \AA$; dan donor $\mathrm{HB}$ dan akseptor $\mathrm{HB} \leq 12$. Sedangkan Egan's rule menyatakan, bahwa senyawa yang memiliki bioavailibilitas oral yang baik jika: $\mathrm{o} \geq$ tPSA $\leq 132 \AA$ dan Nilai $\log \mathrm{P} \leq 5$.

Profil keamanan dari senyawa gendarusin ditentukan dengan program FAF-Drugs4 dan hasilnya ditunjukkan pada Gambar 2. Berdasarkan Pfizer 3/75 Rule Positioning, senyawa yang berada di kotak merah cenderung menyebabkan toksisitas, sedangkan senyawa gendarusin berada pada kotak hijau yang artinya tidak toksik.
TABEL 1. Hasil Skrining Ligan Menggunakan FAF-Drugs4.

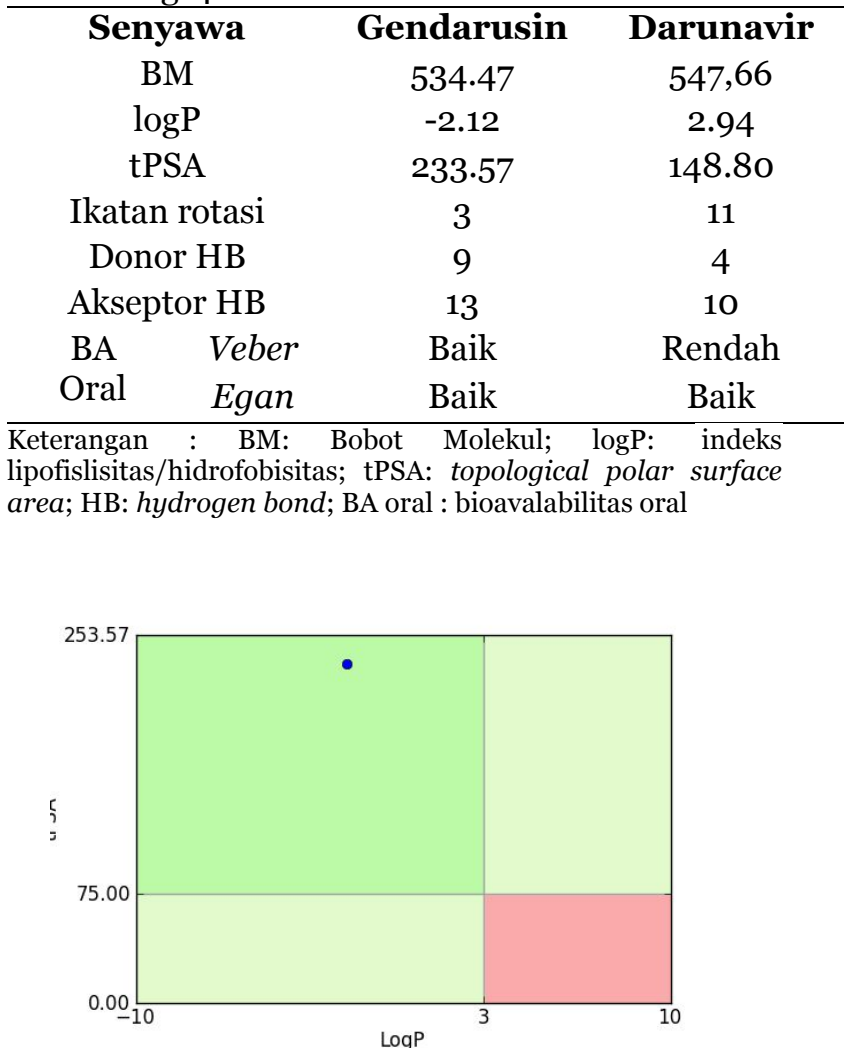

GAMBAR 2. Profil Keamanan Gendarusin (•) Berdasarkan Pfizer 3/75 Rule Positioning.

\section{Prediksi Aktivitas dengan Docking dan Analisis Asam Amino}

Reseptor Protease yang telah di unduh pada situs Protein Data Bank dengan kode 4HLA, dan telah di import pada program Molegro Virtual Docker ditunjukkan pada Gambar 3.

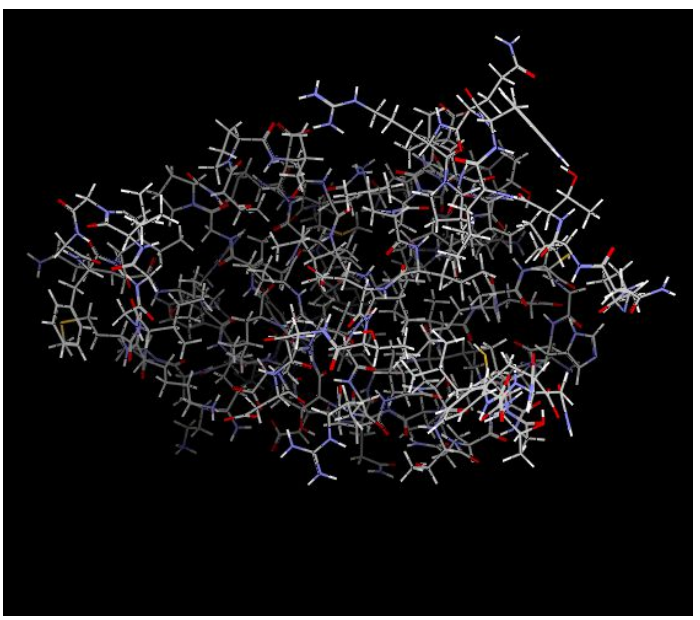

GAMBAR 3. Reseptor Protease (PDB ID : 4HLA)

Hasil deteksi tempat berinteraksi antara ligan dan reseptor (cavity) pada reseptor Protease (4HLA) ditunjukkan dengan Gambar 4. Cavity yang digunakan adalah pada volume 92.16 dengan luas permukaan 323.84. Cavity) ini digunakan karena memiliki area dimana ligan asal berinteraksi dengan enzim protease. 


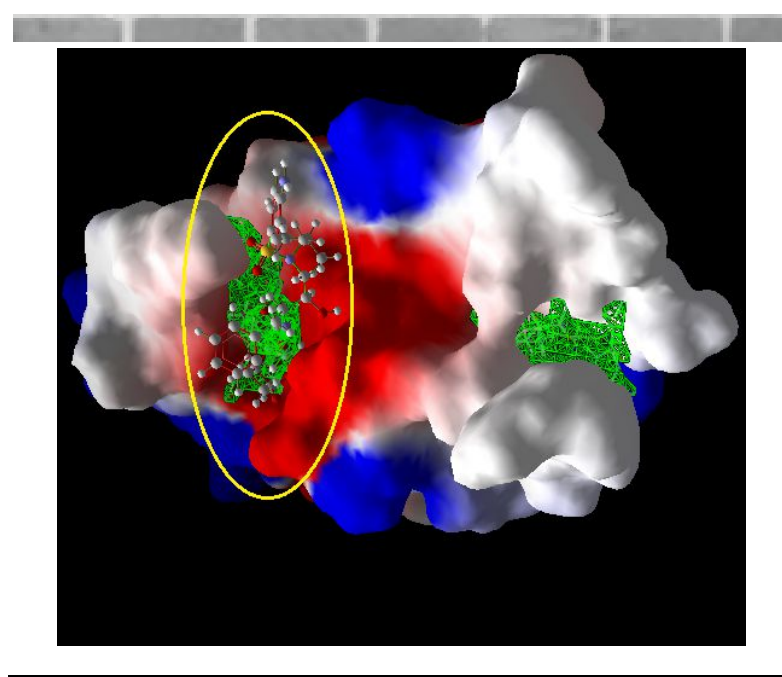

GAMBAR 4. Cavity [Volume=92.16].

Pada interaksi antara ligan dan reseptor terdapat interaksi ligan dengan beberapa asam amino residu dari reseptor Protease (4HLA). Asam-asam amino yang terlibat pada proses interaksi senyawa gendarusin dengan reseptor Protease (4HLA) dapat dilihat pada Tabel 2 dan Tabel 3. Interaksi dari residu asam amino reseptor Protease dengan senyawa terjadi melalui ikatan hidrogen maupun ikatan sterik, dari tabel tersebut dapat dilihat perbedaan interaksi antara masingmasing senyawa gendarusin dengan reseptor Protease (4HLA), hal tersebut karena ada perbedaan konfigurasi ruang dari struktur senyawa-senyawa gendarusin.

TABEL 2. Interaksi Ikatan Hidrogen Reseptor Protease HIV-1 (4HLA) dengan Senyawa Gendarusin.

\begin{tabular}{ccccccc}
\hline Asam & Da & GA & GB & GC & GD & GE \\
Amino & & & & & \\
Asp29 & + & + & - & - & + & - \\
Asp30 & + & + & + & + & + & + \\
Gly51 & - & + & - & + & - & - \\
Gly27 & - & - & + & + & - & - \\
Thr80 & - & - & + & - & - & - \\
Asp25 & - & - & - & + & - & - \\
Ile50 & - & - & - & + & - & + \\
Gly48 & - & - & - & - & + & + \\
Gly49 & - & - & - & - & + & - \\
Gly52 & - & - & - & - & + & - \\
\hline
\end{tabular}

Hasil skor doking dari senyawa gendarusin dengan reseptor Protease (4HLA) (Tabel 4), terlihat bahwa urutan nilai rerank score dari senyawa gendarusin dari rendah ke tinggi adalah gendarusin $\mathrm{B}>$ gendarusin $\mathrm{D}>$ gendarusin $\mathrm{C}>$ gendarusin $\mathrm{E}>$ gendarusin A. Rerank score merupakan nilai yang mencerminkan energi ikatan yang dibutuhkan untuk membentuk ikatan antara ligan dan reseptor, sehingga dari nilai tersebut dapat diprediksi aktivitas dari suatu senyawa. Semakin rendah nilai rerank score maka ikatan antara ligan dan reseptor juga akan semakin stabil sehingga aktivitasnya juga dapat dikatakan semakin tinggi dibandingkan dengan senyawa yang mempunyai nilai rerank score lebih tinggi. Hasil simulasi doking diatas dapat diprediksi bahwa gendarusin B memiliki aktivitas yang lebih tinggi dibandingkan dengan gendarusin lainnya.

TABEL 3. Interaksi Ikatan Sterik Reseptor Protease HIV-1 (4HLA) dengan Senyawa Gendarusin

\begin{tabular}{ccccccc}
\hline Asam & Da & GA & GB & GC & GD & GE \\
Amino & & & & & & \\
\hline Asp29 & + & + & + & + & + & - \\
Asp30 & + & + & + & + & + & + \\
Gly51 & - & + & - & + & - & - \\
Gly27 & - & - & + & + & + & + \\
Thr80 & + & - & + & - & - & - \\
Asp25 & - & + & - & + & - & - \\
Ile50 & - & + & - & + & + & + \\
Gly48 & + & + & + & + & + & + \\
Gly49 & + & + & - & - & + & + \\
Gly52 & - & - & - & - & + & - \\
Val82 & + & - & - & - & - & - \\
Ile54 & + & + & + & - & + & - \\
Phe53 & - & + & - & - & + & - \\
Ile47 & - & - & + & - & + & + \\
Pro81 & - & - & - & + & - & - \\
\hline
\end{tabular}

Keterangan :

Da : Darunavir; GA : Gendarusin A; GB : Gendarusin B; GC : Gendarusin C; GD : Gendarusin D; GE : Gendarusin E.

TABEL 4. Nilai rerank score Darunavir dan Gendarusin

\begin{tabular}{cc}
\hline Senyawa & Rerank Score \\
\hline Darunavir & -86.6954 \\
Gendarusin A & -90.4079 \\
Gendarusin B & -102.706 \\
Gendarusin C & -96.1779 \\
Gendarusin D & -96.585 \\
Gendarusin E & -96.0895 \\
\hline
\end{tabular}

\section{KESIMPULAN}

Hasil studi in silico didapatkan bahwa gendarusin $\mathrm{A}, \mathrm{B}, \mathrm{C}, \mathrm{D}$, dan $\mathrm{E}$ memiliki aktivitas sebagai Protease inhibitor HIV-1, dengan aktivitas paling tinggi adalah gendarusin B. Senyawa gendarusin juga memiliki bioavailabilitas oral yang baik dan tidak toksik, sehingga berpotensi dikembangkan sebagai anti-HIV.

\section{UCAPAN TERIMA KASIH}

Ucapan terima kasih penulis sampaikan kepada Prof. Dr. Siswandono, Apt.,MS. dari Fakultas Farmasi Universitas Airlangga yang mempunyai lisensi software Molegro. 


\section{DAFTAR PUSTAKA}

Chakravarty, AK., Dastiar, PPG., and Pakrashi, SC. 1982. Simple Aromatic Amines from Justicia gendarussa ${ }^{13} \mathrm{C}$ NMR Spectra of the Bases and Their Analogues. Tetrahedron, 18(12): 1797-1802.

Egan W.J, Merz K.M. Jr., and Baldwin J.J. 200o. Prediction of Drug Absorption Using Multivariate Statistics. J. Med. Chem, 43: 3867-3877.

Kiren, Y., Deguchi, J., Hirasawa, Y., Morita, H., and Prajogo, B. 2014. Justodrusamides A-D, new 2-aminobenzyl Alcohol Derivatives from Justicia gendarussa. Journal of Natural Medicines.

Ko, Y-J., Oh, H-J., Ahn, H-M., Kang, H-J., Kim, J-H., and Ko, YH. 2009. Flavonoids as Potential Inhiibitors of Retroviral Enzymes. J. Korean Soc. Appl. Biol. Chem, 52(4): 321-326.

Markus H.J. Seifert, Kristina Wolf, and Daniel Vitt, 2003. Virtual high-throughput in silico screening. Biosilico, 1(4).

Pattman R., Snow M., Handy P., Sankar K. N., and Elawad B., 2005. Oxford Handbook of Genitourinary Medicine, HIV, and Aids, 1st Edition. Oxford University Press, pp. 346-359.

Prajogo, B. 2014. Autentik Tanaman Justicia gendarussa Burm. f. Sebagai Bahan Baku Obat Kontrasepsi Pria. Surabaya: Airlangga University Press dengan LP3 UNAIR.

Prajogo, B., Guliet, D., Queiroz, F, Wolfernder, J-L., Cholies, N., Aucky, H., and Hostettmann, K. 2009. Isolation of Male Antifertility Compound in n-Butanol Fraction of Justicia gendarussa Burm.f. Leaves. Folia Medica Indonesiana, 45(1): 28-31.

Prajogo, B., Widiyanti, P., and Riza, H. 2014. Effect of Ethanolic Extract of Justicia gendarussa Burm f. Against Activity of Reverse Transcriptase HIV Enzyme In Vitro. Jurnal Bahan Alam Indonesia, 8(6): 384-388.

Veljkovic, V., Mouscadet, J-F., Veljkovic, N., Glisic, S., and Debyser, Z. 2007. Simple Criterion for Selection of Flavonoid Compounds With Anti-HIV Activity. Bioorganic and Medicinal Chemistry Letters, 17: 1226-1232.

Widiyanti P., Prajogo B., and Hikmawanti N.P.E. 2015. Cytotoxicity of Justicia gendarussa Burm.f. Leaf Extracts on MOLT-4 Cell. Indonesian Journal of Tropical and Infectious Disease, 5(7): 188-192.

Siswandono, 2011. Studi pemodelan molekul interaksi beberapa turunan penisilin dengan reseptor DDTranspeptidase dari streptomyces R61 (1PWC), Majalah Farmasi Airlangga, 9(2).

Veber D.F., Johnson S.R., Cheng H.Y., Smith B.R., Ward K.W., and Kopple K.D. 2002. Molecular Properties That Influence the Oral Bioavailability of Drug Candidates. J. Med. Chem. 45: 2615-2623.

Yanuar A., Mun'im A.Lagho A.B.A., Syahdi R.R., Rahmat M., and Suhartanto H. 2011. Medicinal Plants Database and Three Dimensional Structure of the Chemical Compounds from Medicinal Plants in Indonesia. International Journal of Computer Science Issues, 8(5). 